conducted archæological excavations in New Mexico and Hungary. In addition to being recognized as an authority on the material cultures and art of the peoples of South America, he is well known as a connoisseur in art.

\section{International Management Congress}

Preumininary notice has just been received of the seventh International Management Congress, which will take place in Washington during September 1938. This will be the first of the series to be held in the United States, and it will provide the most favourable opportunity which is likely to occur for many years of seeing examples of the application of American management methods to business undertakings. Two main themes are proposed for the Congress: (a) recent developments in scientific management; (b) economic and social aspects of scientific management. The papers which are accepted will be classified under one of the following six heads : administration, production, distribution, personnel, agriculture, the home. It is proposed to preface the discussions by an authoritative review of the history of scientific management up to the time of the London Congress, which will be based on reports previously prepared by each of the national committees. The organization of the British participation in the Congress is in the hands of the newly formed. British Management Council, the Secretary of which is Mr. U. Baliol Scott, Armour House, E.C.l.

\section{Scholarships in Electrical Engineering}

Applications, which must be received not later than April 15, are invited for the following scholarships awarded by the Institution of Electrical Engineers. Inquiries for full particulars and nomination forms (specifically mentioning the name of the scholarship) should be addressed to the Secretary of the Institution, Savoy Place, London, W.C.2. Duddell Scholarship (value $£ 150$ per annum, tenable for three years), open to British subjects under nineteen years of age on July 1, 1937, who wish to take up a wholetime day course in electrical engineering. Ferranti Scholarship (value $£ 250$ per annum, tenable for two years), open to British subjects under twenty-six years of age on July 1, 1937, who are students or graduates of the Institution of two years standing and desire to carry out whole-time research or postgraduate work of an electrical engineering nature. Swan Memorial Scholarship (value $£ 120$, for one year), open to British subjects under twenty-seven years of age on July 1, 1937, who desire to carry out whole-time research or post-graduate work of an electrical engineering nature. Silvanus Thompson Scholarship (value $£ 100$ per annum and tuition fees, tenable for two years), and William Beedie Esson Scholarship (value $£ 120$ per annum, tenable for two years, renewable in approved cases for a third year), for works employees, open to British subjects less then twenty-two years of age on July 1, 1937, for wholetime instruction in electrical engineering at an approved university or technical college.

\section{New Fellows of the Royal Society of Edinburgh}

AT the ordinary meeting of the Royal Society of Edinburgh, held on March 1, the following ordinary fellows were elected: Dr. A. J. G. Barnett, lecturer in chemistry, Education Department, Nigeria; $\mathrm{Mr}$. Biswas Kalipada, curator of the Herbarium, Royal Botanic Garden, Calcutta; Dr. J. J. Black, manufacturing chemist, Edinburgh; Prof. Max Born, Tait professor of natural philosophy, University of Edinburgh; Mr. G. B. Brook, chief chemist, British Aluminium Co., Ltd., London; Mr. A. G. R. Brown, manager and actuary, Life Association of Scotland, Edinburgh; Mr. C. J. Cousland, Edinburgh; Dr. W. S. McR. Craig, Medical Officer, Ministry of Health, Whitehall, London; Dr. S. C. Dhar, head of Mathematics Department, College of Science, Nagpur, C.P., India; Dr. H. P. Donald, research assistant, Institute of Animal Genetics, University of Edinburgh; Prof. D. M. Dunlop, Christison professor of therapeuties, University of Edinburgh ; Prof. R. C. Garry, Department of Physiology, University College (University of St. Andrews), Dundee; Dr. A. R. Gilchrist, assistant physician, Royal Infirmary, Edinburgh, and lecturer in therapeutics, University of Edinburgh; Dr. G. Green, lecturer in applied physics, University of Glasgow; Mr. W. A. F. Hepburn, director of education, Ayrshire Education Authority; Prof. P. R. Kirby, professor of music and musical history, University of the Witwatersrand, Johannesburg, South Africa; Dr. P. C. Koller, cytologist, Institute of Animal Genetics, University of Edinburgh; Mr. W. O. Leitch, civil engineer, Edinburgh ; Dr. H. W. Melville, fellow of Trinity College, Cambridge; Mr. James Miller, Stirling; Lieut.-Colonel J. Morison; Mr. Roy Nasmith, United States Consul in Edinburgh ; Mr. T. T. Paterson, fellow of Trinity College, Cambridge; Dr. J. D. Pollock, Edinburgh; Dr. B. N. Prasad, lecturer in pharmacology, P. W. Medical College, Bankipore, P.O., Bihar, India ; Mr. F. I. G. Rawlins, scientific adviser to the Trustees of the National Gallery, London; Dr. M. Ritchie, assistant lecturer in chemistry, University of Sheffield; $\mathrm{Mr}$. J. W. Robertson, headmaster, Central School, Aberdeen ; The Hon. Lord Robertson, a senator of the College of Justice, Edinburgh; Dr. W. R. Russell, assistant physician to the Royal Infirmary and to the Deaconess Hospital, Edinburgh; Dr. J. K. Slater, assistant physician, Royal Infirmary and physician to the Deaconess Hospital, Edinburgh; Dr. A. M. Smith, lecturer in agricultural chemistry, University of Edinburgh ; Mr. H. G. Smith, assistant, Department of Natural History, University of Aberdeen ; Dr. H. M. Steven, divisional officer, Forestry Commission, Aberdeen; The Right Hon. the Earl of Suffolk and Berkshire, Eskbank, Midlothian; $\mathrm{Mr}$. J. G. Tait, scholar of Peterhouse College, Cambridge and formerly principal, Central College, Bangalore, India ; Dr. H. Tod, biochemist, West House, Edinburgh; Mr. M. McK. Tumbull, lecturer in banking, University of Edinburgh; Prof. E. M. Wright, Department of Mathematics, University of Aberdeen; Mr. A. W. Young, Writer to the Signet, Edinburgh. 